\title{
The relevance of potato farming in the agricultural economy (on the example of the Republic of Uzbekistan)
}

\author{
Dilobar Islamova ${ }^{1}$, Umirzok Kholiyorov ${ }^{1, *}$, Khusan Dustmukhammad ${ }^{1}$, Fakhriddin \\ Shafkarov ${ }^{1}$, and Kakhkhor Numonov ${ }^{2}$ \\ ${ }^{1}$ Andijan Institute of Agriculture and Agro Technologies, 1 Oliygokh Street, Kuygan-Yor town, \\ 170600, Andijan region, Uzbekistan \\ ${ }^{2}$ Tashkent institute of irrigation and agricultural mechanization engineers, 39, Kari Niyazov Street, \\ 100000, Toshkent, Uzbekistan
}

\begin{abstract}
In a difficult situation, with the unstable economic situation in the world, in a number of countries, the main element of increasing the economic activity of commodity producers is an extensive study of the activities, in terms of the importance of production, of certain types of products in the food sector. The study is very relevant, it determines the importance of potatoes as a food crop and commodity. Ways of ensuring a reliable system of operation of the potato growing sector are being investigated. The potato growing sector is of great importance, potatoes are one of the popular food crops that create stability and support a nutritious diet for the country's population. The development of the potato sector is based on the trends of the general economic development of the country and it should be emphasized such factors as the state economic policy and strategy for the development of the agricultural sector, trends in demographic development in rural areas, the current state of the production system, industry-wide trends in the functioning of the potato market in the country and in the world. The study examined the modern place of potatoes in the human diet, and the importance of potatoes in food and economic value for the population of the Republic of Uzbekistan.
\end{abstract}

\section{Introduction}

Since ancient times, potatoes have played a significant role in ensuring the food security of the Republic of Uzbekistan and many other countries of the world. As everyone knows, the homeland of potatoes is South America. Potatoes as a consumable crop were introduced about 9-7 thousand years ago in Bolivia.

In the Republic of Uzbekistan, potatoes appeared in the middle of the 19th century, near Tashkent in the villages of Nogaykurgan and Brichmulla. It was brought from Western Siberia. The main development of potato growing as an industry was at the turn of the 19th and 20th centuries, in connection with the appearance of the railway, and stations in

\footnotetext{
${ }^{*}$ Corresponding author: sb.i.1@mail.ru
} 
industrial and administrative centers, where the Russian population predominated, which was the main consumer of potatoes.

Potatoes are a special important crop that is of great importance in the nutrition of the population. Potatoes are grown in 150 countries of the world on an area of 19-20 million hectares, the gross yield is $370-390$ million tons.

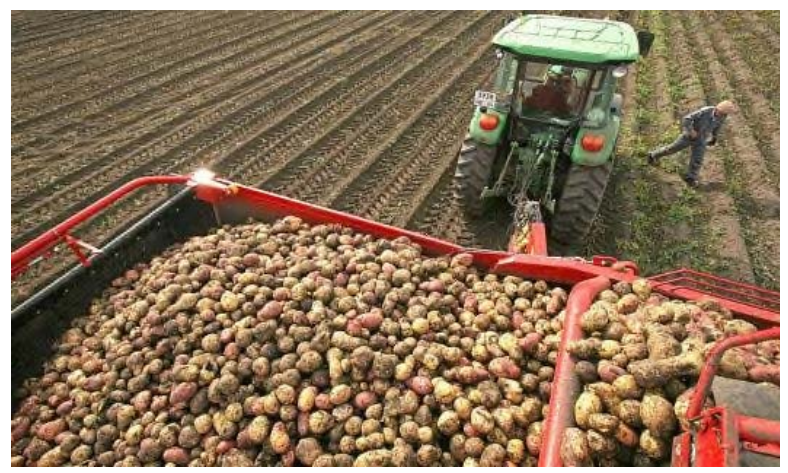

Fig. 1. Picking potatoes.

Potato is an economically affordable product, therefore there is always a demand for it, its share in the diet is 20 percent). Potatoes are used not only as a food product, but also as a fodder, industrial crop. The use of potatoes is very versatile, and there are a lot of potato varieties, any consumer can choose a suitable variety for himself.

Potatoes in the Republic of Uzbekistan, and mainly in the CIS, are consumed fresh, about 5 percent are processed for semi-finished products, in European countries and the United States - half of the harvested crop is processed for semi-finished products.

Due to its characteristics, potatoes are of high importance in the food and economic sectors. Potatoes have natural characteristics, they are positive and negative:

1- Potatoes are able to maintain their appearance and their properties for a certain time, without loss of mass and microbiological properties. Certainly, if you follow all the conditions of cultivation, weather conditions, correct transportation and storage.

2- Potatoes are a bulky product, therefore, require special storage and transportation conditions. It is perishable, and therefore more transport and storage costs are spent than other horticultural crops.

3- Potatoes reach ready-to-eat conditions during storage.

4- The quality of potatoes is affected by weather conditions

5- Potatoes have many alternative markets. Potatoes can be seen in different forms on the market (fresh, frozen, dried, etc.), at any time of the year (winter, spring, summer, autumn), in any country and city.

6- The properties of the potato cannot be changed due to genetics.

In the world, the main potato producers are China - 95.6 million tons, India - 46.4 million tons and Russia -31.5 million tons. The average potato yield around the world is 18 $\mathrm{t} / \mathrm{ha}$, the highest yield is $40 \mathrm{t} / \mathrm{ha}$, the lowest is from 3 to $5.5 \mathrm{t} /$ ha. Every year, $34.2 \mathrm{~kg}$ of potatoes are produced per capita in the world. In the leading countries of Belarus, Ukraine, Latvia, Russia, Kazakhstan and others in the range of 100-183 kg of potatoes per capita.

The Republic of Uzbekistan has a favorable climate for growing potatoes. In the Republic of Uzbekistan, according to data for January-June 2019, 1,469,863 tons of potatoes were received. The leaders in growing potatoes in the Republic of Uzbekistan are Samarkand region - 295,924 tons of potatoes, Fergana region - 184,118 tons of potatoes. The smallest amount of potatoes is produced in the Jizakh region - 9236 tons of potatoes. 
The potato market is quite unusual. The structure of the potato market is determined by several factors: the socio-economic situation in local places, the demand for solvency, the volume of the domestic and foreign markets, the correspondence between the price and quality of the product. The potato market is characterized by the following features:

- The area of distribution of potatoes is very extensive, the development of the market depends on interregional and interstate relations.

- Geographic location of potato production near consuming regions, the existence of transport routes that contribute to the level of development of links between regions for the transportation of raw and processed potatoes.

- The demand for potatoes is poorly elastic. It is associated with the long-term traditions of eating potatoes and the population's ability to pay. The elasticity of potatoes is due to the fact that the population gives preference to other crops of potatoes, because of their price and taste.

- The offer for potatoes is poorly elastic, due to the inertial specifics of production.

- The potato industry has high risks and low profitability.

- The costs of material and money for storage are high, all this affects the price of the product. The costs are related to the fact that the main part of potatoes comes to the market in the autumn, and in winter and spring from warehouses.

\section{Methodology}

The study of the topic is based on general scientific research methods. The mechanism and structure of the development of potato growing were subjected to detailed analysis. The efficiency of potato growing in the country and in the world as a whole is revealed. The potato market is analyzed. The analysis of the potato market corresponds to the following scientific principles, namely: consistency, complexity, objectivity, practical implementation. Additionally, some principles were used for a complete study of the potato market, these are focus on exact problems (identification of problems associated with economic development and control of the potato market) and market segmentation.

The study of the potato market is carried out in three directions: the study of the empirical foundations of the economic development of the potato market, analysis of the state and development prospects of the potato market, priority areas for improving and controlling the local potato market.

\section{Result}

During the years of independence of the Republic of Uzbekistan, the potato yield has almost quadrupled. From table 1, it can be seen that at the beginning, an average of 85 centners of potatoes were obtained from each hectare, and at the moment it reaches 250 centners of potatoes. In 1991, more than 300 thousand tons of potatoes were cultivated in the Republic of Uzbekistan, at the moment this figure is over 2 million tons.

Table.1. Dynamics of potato production in Uzbekistan.

\begin{tabular}{|l|l|l|}
\hline Indicators & 1990 & 2020 \\
\hline Yields, c & 85 & 250 \\
\hline Gross collection, million tonnes & 0,3 & 2 \\
\hline
\end{tabular}

The prime cost of potatoes is very peculiar; it has a complex composition. The prime cost includes a large complex of material and labor costs for cultivation, collection, sorting and storage. The costs of potato growing are associated with a large volume of production. When cultivating potato, a large number of agro-technical measures are carried out (soil 
preparation, fertilizing the soil with organic fertilizers, planting, harvesting, and so on) associated with high energy consumption, and huge costs for maintaining the working condition of equipment, purchasing spare parts, fuel and lubricants, and maintaining warehouses and so on. Few organizations are involved in the cultivation of potatoes for sale.

The costs of potato growing are multifaceted, they include: wages with deductions for social insurance, costs of planting material, organic and mineral fertilizers, various plant protection products, various energy (electrical, thermal), fuel, spare parts, services of organizations, not directly related to transportation, improvement of land reclamation, depreciation of fixed assets and other expenses. The above costs are not listed in the reports, they are combined into one whole, for calculating and assessing the structure of the cost of finished goods.

Potatoes are a high-yield crop and a high investment. With high yields, the costs are correspondingly higher. But the cost per $1 \mathrm{~kg}$ of potatoes and its cost with high yields are lower. In the Republic of Uzbekistan, the average potato yield is $16 \mathrm{t} / \mathrm{ha}$, respectively, at current market prices, the cultivation of this crop is profitable. Such a contribution to the development of the potato industry is made by existing large firms and cooperatives engaged in the production of seed potatoes and special equipment.

The potato industry all over the world has a number of problems that do not allow development.

The following obstacles stand out:

- there are no effective marketing strategies for promoting local seed, food grade potatoes, as well as products obtained after processing to the domestic and foreign markets;

- there is a lack of coordination in reproduction and ensuring a balance of demand and volumes of products, varietal seed, ware potatoes and an assortment of potato products that are in great demand both in Uzbekistan and in other countries of the world;

- Lack of local equipment for harvesting potatoes, sorting equipment, washing, processing, packing and packaging and new modern machines for the production of new varieties and types of products from potatoes;

- non-compliance with the requirements of the storage conditions, namely, the wrong system for maintaining the temperature and humidity regime and ventilation, and the potato processing shop, bringing it to the sale in the retail network;

- ageing of the material and technical base of potato breeding, both physically and mentally, lack of a system for providing high-quality seed materials;

- Lack of working capital to attract investment loans for large amounts for the reconstruction of existing, construction of new cooperatives of potato storage facilities, the purchase of high-performance agricultural equipment and improvement of the system for bringing products from the field to the consumer;

- low level of subsidies that are allocated by the state to agricultural producers to compensate for losses in case of force majeure.

Another important task is the marketing of products. Potatoes are a mandatory product in the consumer's basket, so it is a difficult task to get customers interested in a new variety of potatoes.

When analyzing the formation of retail prices, it was revealed that manufacturers would be able to earn more income if they self-sold their own products. When studying the sales system and the economic evaluation of sales channels, it was found that the system for studying sales markets is poorly developed. The reason for this is the lack of experience in applying marketing in practice, short-and long-term planning, and the imperfection of the market research base, namely the information part.

You can try to take up the marketing part of selling potatoes, but this is a risky business. To actively involve the sale of potatoes it is necessary to improve the shape of the 
packaging. As with any other product, the packaging attracts the attention of consumers. You can apply a special form of packaging to commonly used products, such as potatoes. As everyone knows, potatoes are sold in markets mainly in grids, where the consumer can see their products, but at the same time they contain a large amount of earth impurities, which pollutes the consumer's products or clothing. Also in the markets, potatoes are Packed in a plastic bag for the consumer, and many consumers store potatoes at home. This form of packaging forms condensate and reduces its shelf life. The most appropriate form of packaging is a paper bag (although it is an expensive option). In figure 1, we see the potatoes in the grid that the potatoes are currently being Packed in, and the potatoes in the packaging of a paper bag mix with the grid. In this case, we believe that the second method of packaging will create additional interest in potatoes.
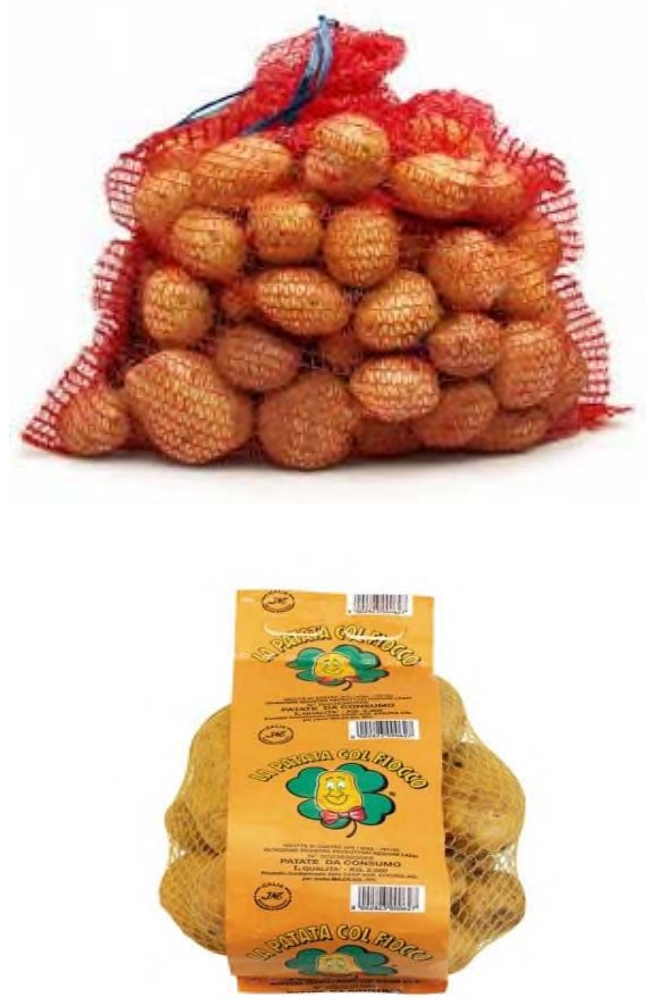

Fig. 2. Types of potato packaging (traditional-mesh and modern - mesh-paper with a handle).

To further attract the consumer to the sport of specially grown potatoes, it is appropriate to conduct a tasting, bake the potatoes in cubes and offer them to the buyer. After tasting this type of potato, the consumer can take it to special dishes where potatoes are mainly used.

\section{Discussion}

In Uzbekistan, a huge amount of work is being done to develop the potato market. A number of reforms, laws and decrees improve the situation related to the provision of potatoes not only on the domestic market, but also on the external one. 
The Republic of Uzbekistan creates favorable organizational and financial conditions for the development of the industry. The Ministry of agriculture of the Republic of Uzbekistan has formed and approved the departmental target program "Comprehensive measures for the development of seed production and potato cultivation in the Republic for the period 2018-2020" to develop the production of highly productive potato seeds to meet the needs of the domestic market [12].

On May 6, 2020, President of the Republic of Uzbekistan Sh. Mirziyoyev adopted a resolution on expanding potato production and developing seed production in the Republic of Uzbekistan. According to the decree, potato clusters and cooperatives will be created in areas where they specialize in this industry. They will work on the production of consumer and seed potatoes, meeting the demand for potatoes in the local market, and creating added value in this area [13].

This decree helped Finance the costs of purchasing seed potatoes for farmers and agricultural enterprises that produce potatoes. Clusters and cooperatives are granted loans for up to a year. The state Fund for business support compensates for the following types of expenses:

- the percentage of the interest rate on commercial loans issued in the national currency that exceeds the main rate of the Central Bank, but not more than $10 \%$ points.

- up to 30 percent of the interest rate on loans issued in foreign currency, but not more than three percentage points.

Also, seed potatoes are exempt from customs duties until July 1, 2023, imported from abroad. Benefits are granted only on the basis of the act of quarantine inspection of the state plant quarantine Inspectorate under the Cabinet of Ministers of the Republic of Uzbekistan and the certificate of conformity of The Inspectorate for control of agriculture.

A new Fund has been formed without forming it as a legal entity, a Fund for financial support of scientific research and innovative developments, the development of potato varieties and potato seed breeding at the research Institute of vegetable and melon crops and potato production. The Fund's funds will be used to Finance scientific research and innovative developments in vegetables, melons and potato production, as well as to motivate authors who are engaged in creating new varieties of vegetables, melons and potatoes.

The Ministry of innovative development is engaged in the creation of early-maturing, medium-maturing and late-maturing local potato varieties that can resist various negative factors.

To establish primary seed production of local varieties of potato research Institute bombacci cultures and transferred to potato 17.2 hectares of land, which is located on the territory of the rural-public terrain, "Soulik" in Bostanlyk district of Tashkent region. The massif Squeak of the state forest farm "Burchmulla" organized seed potato production high reproduction.

It is necessary to highlight the main strategies for the development of potato production:

1) Strategic goal-this uses the natural resources of the area, stable provision of local needs for marketable potatoes.

2) Principles are an approach based on a systematic approach with a combination of economic interests, integration of state regulation and market self-regulation, and justification based on economic principles.

3) Integration of various priorities of the potato growing and the potato market, such as the competitiveness of potato products, the introduction of resource-saving technologies, the renewal of equipment in the potato industry, the rational placement of potato producing enterprises, the sale of potato products, the provision of qualified personnel, the improvement of infrastructure in rural areas. 
If this strategy for the development of potato growing, it is possible to achieve new effective forms of management, the development of investment projects, technical and technological re-equipment of the potato industry, the structure and volumes of production and consumption of potatoes, an increase in potential, taking into account the soil-climatic and economic conditions of the area.

\section{References}

1. D.M. Parmakli, Bulletin of NGIEI, №11(54), 75-79 (2015)

2. D.N. Kozhomkulova, Bulletin of NGIEI, №3(46), 53-59 (2015)

3. D.A. Derzhavina, Bulletin of NGIEI, №3(46), 37-45 (2015)

4. V.V. Popovich, I.V. Kolmogorova, Baltic Humanitarian Journal, 3, 80-83 (2014)

5. I. Nikitina, Agrarian economy, 8, 40-44 (2012)

6. A. Zhukov, Belarusian agriculture, 4, 92-95 (2014)

7. G.I. Piskun, L.N. Kozlova, Our agriculture, 9, 87-91 (2015)

8. T.N. Sidorenko, Our agriculture, 23, 34-37 (2015)

9. G.I. Podluzhny, Scientific bases of potato growing in the Mogilev region: monograph (ITC of the Ministry of Finance, Minsk, 228, 2005)

10. V. Stukach, M. Yakubenko, Economy of agriculture of Russia, 11, 32 - 33 (2007)

11. H.Ch. Buriev, V.I. Zuev, L.A. Gafurova, Potato growing in Uzbekistan (Tashkent, 60, 2004)

12. Resolution of the President of the Republic of Uzbekistan No. PP-3558 dated 02.23.2018 "On measures for the further development of seed potato cultivation in the republic." Newspaper "Narodnoye Slovo" from 25.02.2018

13. Resolution of the President of the Republic of Uzbekistan No. 4704 "On measures to expand potato production and further development of potato seed production in the republic" dated 06.05.2020 